\title{
DIALEKTIKA BUK SEBAGAI BENTUK KESEDERHANAAN MATERIALITAS DALAM SPASIALISASI ARSITEKTUR DI DUSUN MALANGSUKO MELALUI PERSPEKTIF EKISTICS
}

\author{
Yusfan Adeputera Yusran ${ }^{*}$, Afidz Aditya Utama² \\ Jurusan Arsitektur, Universitas Brawijaya, Malang, Indonesia \\ e-mail: *1yusfan@ub.ac.id, ${ }^{2}$ afidzaditya111@gmail.com
}

\begin{abstract}
Abstrak_ Budaya dalam suatu ruang muncul sebagai respon manusia dalam memaknai tempatnya beraktivitas. Seiring semakin intensnya digunakan, ruang itu dapat memberikan makna yang mendalam bagi penggunanya. Penelitian ini mengangkat sebuah fenomena yang terjadi di Jalan Melati, Desa Malangsuko, Malang yaitu sebuah konstruksi lokal sederhana pengaman selokan yang bernama Buk dapat menciptakan ruang interaksi yang intens digunakan oleh masyarakat setempat. Lama-kelamaan ruang ini cenderung membentuk sebuah budaya interaksi yang mewarnai kehidupan sehari-hari masyarakatnya. Secara eksploratori, penelitian ini diawali dengan mengkaji kondisi riil Buk di lokasi untuk mendapatkan bagaimana peran Buk dalam terciptanya ruang budaya. Melalui perspektif Ekistics, fenomena keberadaan Buk dibaca dengan menggunakan aspek alam (nature), manusia (man), masyarakat (society), naungan (shells), dan jaringan (network). Disamping itu, dilakukan pula kuantifikasi hasil kajian kualitatif tersebut dengan menyebarkan kuesioner kepada masyarakat yang tinggal di sepanjang Jalan Melati Desa Malangsuko. Hasilnya menunjukkan bahwa memang proses sosial di dalamnya merupakan hasil dari bagaimana masyarakat di tempat ini memanfaatkan Buk ini dan sekaligus menjadikannya tempat berinteraksi. Proses sosial yang terjadi di tempat ini menunjukkan bahwa Buk memiliki peran sebagai pendukung terjadinya interaksi yang saling berkesinambungan serta memperlihatkan bagaimana manusia menciptakan sebuah elemen konstruksi sederhana sebagai tanggapan alam yang kemudian dimanfaatkan oleh mereka sehari-hari.
\end{abstract}

Kata kunci : Arsitektur yang Sederhana; Ekistics; Spasialisasi.

\begin{abstract}
Abstract_Culture in a space arises as a human response to interpret their activity's place. As more and more intensely used, space can give a deep meaning to its users. This research attempts to raise a phenomenon that occurs in Jalan Melati in Malangsuko hamlet, Malang where a simple local construction for the gutter safety called Buk can create an intense interaction space used by the local community. Over time this space tends to form a culture of interaction that colours the daily lives of the locals. Exploratively, this study began by examining the real condition at the site to get the role of the Buk in creating cultural space. From the Ekistics perspective, the existence of Buk is read using the five ekistics' principles; Nature, Man, Society, Shells, and Network. Also, the obtained qualitative study results were quantified by distributing questionnaires to the locals who live along Jalan Melati. The results show that the social process in it is a result of how the locals use this Buk and, at the same time, make it a place to fulfil their social needs. The social processes that occur at there show that Buk has a role as a supporter of continuous interaction and shows how the locals create a simple construction element in response to nature and then utilized it on their daily basis.
\end{abstract}

Keywords: Ekistics; Inornate Architecture; Spatialization.

\footnotetext{
${ }^{1}$ Jurusan Arsitektur, Universitas Brawijaya, Malang, Indonesia 2 Jurusan Arsitektur, Universitas Brawijaya, Malang, Indonesia
} 


\section{PENDAHULUAN}

Permukiman merupakan hasil adaptasi manusia terhadap lingkungan di tempat dia menetap serta didasari pada kepercayaan kelompok masyarakat yang diwujudkan dalam bentuk lingkungan tradisional. Konsep tersebut dijalankan dalam unit hunian yang tersusun dalam sebuah pola permukiman yang diturunkan dari generasi ke generasi. Bermukim erat kaitannya dengan tempattempat dan pola-pola ruang yang diciptakan oleh manusia untuk mewadahi kegiatan hidupnya, mulai dari bertempat tinggal, bekerja, berinteraksi dan berkehidupan yang pada akhirnya termanifestasikan menjadi aspek simbolik ruang.

Di Nusantara, pola permukiman yang diterapkan masyarakat umumnya menerapkan pola berjajar memanjang hingga melingkar. Unit hunian berjajar berhadap-hadapan dengan dipisahkan oleh pelataran (halaman) atau jalan di tengahnya (Pangarsa dan Prijotomo, 2010:19). Hal ini memberikan kesempatan bagi jalan sebagai ruang bersama yang dimanfaatkan oleh semua masyarakat. Lebih lanjut menurut Pangarsa dan Prijotomo (2010:19), gang-gang di perkampungan Nusantara dapat dikatakan sebagai contoh representasi dari keberadaan Tanean (di Madura) atau Natar (di Flores). Gang tersebut merupakan ruang bersama karena pola permukiman di Nusantara merupakan pola pemukiman berjajar yang memanjang ataupun melingkar yang saling berhadapan. Konsekuensi dari posisi gang yang berada di tengah hunian yang linear ini menjadikan gang ini Bukan sebagai jalan untuk berlalu lintas pada umumnya. Pola permukiman yang saling berhadapan ini biasanya dipisahkan oleh sebuah gang atau jalan yang lebih dikenal sebagai pelataran atau halaman. Pelataran inilah yang digunakan masyarakat sebagai ruang bersama dengan berbagai aktivitas di dalamnya. Di dalam pelataran ini terdapat beberapa elemen yang digunakan masyarakat dalam bersosialisasi seperti pada Buk, sebuah konstruksi sederhana yang awalnya hanya berfungsi sebagai pengaman pada jembatan di atas selokan, namun ternyata dapat merepresentasikan wujud spasialisasi budaya pada beberapa permukiman di Nusantara.

\section{A. Konsep Ruang di Nusantara}

Ruang bersama merupakan ruang yang selalu menjadi identitas masyarakat Nusantara. Keberadaan ruang bersama merupakan simbol dari masyarakat Nusantara, terutama dalam suatu permukiman, yang memiliki hubungan antar sesama yang baik, ditandai dengan adanya kebersamaan atau keguyuban. Pada masyarakat pedesaan, kebersamaan ini lebih terasa, oleh karena adanya; ikatan kekerabatan, adanya pengalaman hidup yang relatif hampir sama, yakni persamaan jenis pekerjaan, serta persamaan latar belakang (Indeswari et al., 2013:38). Kebersamaan atau keguyuban terasa hampir di setiap waktu dalam kehidupannya. Seiring waktu bentuk kebersamaan ini melembaga menjadi bentuk budaya. Ruang pun menjadi wujud simbolisasi dari budaya ini.

Terbentuknya ruang dipengaruhi oleh perilaku dan karakter manusia yang beraktivitas di ruang tersebut. Ruang yang terdapat aktivitas di dalamnya secara terus menerus akan membentuk sebuah karakter yang kuat sehingga menjadi identitas yang khas dan dapat dirasakan sebagai sebuah tempat atau place (Trancik, 1986). Ruang bersama merupakan bagian dari ruang sosial, hasil dari kehidupan bermasyarakat. Ruang bersama pun bisa dikategorikan sebagai ruang publik, karena pemanfaatannya tidak hanya untuk personal, namun dimanfaatkan oleh sekelompok orang. Ruang bersama dipahami pula sebagai common space, dan banyak diartikan pula sebagai communal space (ruang komunal).

Di Nusantara, ruang bersama dapat dikatakan sebagai shared space (Pangarsa dan Prijotomo, 2010), atau ruang tempat untuk berbagi bersama. Shared open space menurut Sulivan dalam (Darmiwati, 2000) dimaknai sebagai suatu ruang yang terbatas yang digunakan oleh untuk memfasilitasi interaksi antara penduduk dari suatu komunitas. Lebih lanjut, ruang bersama adalah suatu wadah yang menampung berbagai kegiatan kebersamaan masyarakat 
(baik yang positif maupun yang negatif) di dalam memenuhi kebutuhan ekonomi, sosial, budaya warganya (Darmiwati, 2000:119). Ruang, merupakan suatu penghadiran, sehingga dalam terbentuknya ruang terdapat proses yang terjadi dan dipengaruhi oleh faktor sosial, keadaan alam, ekonomi dan lain sebagainya (Indeswari et al., 2013). Dalam pembentukan suatu permukiman, Doxiadis (1970) menawarkan pandangan bahwa dalam human settlements terdapat beberapa faktor yang dapat menjadi parameter penilaian dalam menilai perkembangan permukiman tersebut, yaitu Alam (Nature), Manusia (Man), Masyarakat (Society), Naungan (Shells), dan Jaringan (Network). Berangkat dari pemahaman ini, penelitian ini bertujuan melihat pola pemanfaatan Buk di Jalan Melati, Malangsuko yang merepresentasikan gang sebagai shared space dengan menggunakan parameter Ekistics untuk memudahkan dalam mendeskripsikan fenomena ini secara naratif.

\section{B. Sejarah Buk}

Buk ( \bõ'\) merupakan struktur beton sederhana yang dibangun sebagai pengaman di sisi sebuah jembatan di atas saluran air depan rumah. Jembatan ini lumrah ditemukan sebagai penghubung jalan kampung dengan rumah di Indonesia. Secara historis, Buk sendiri diadopsi dari konstruksi sederhana bambu yang disebut Gek yang diwarisi dari Sunan Drajat, salah satu penyebar Islam (sunan) di tanah Jawa (Nashihin, 2012).

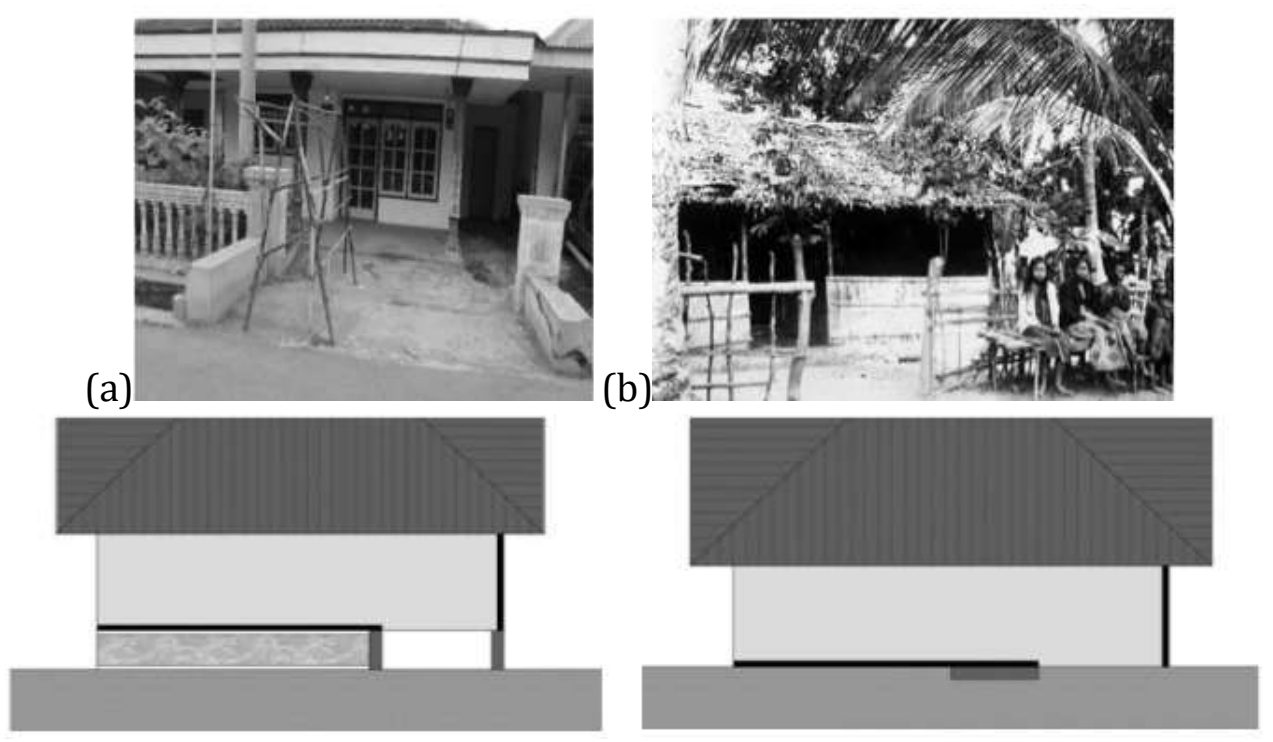

Gambar 1. Beda posisi Buk dan Gek

(a) Buk di Malangsuko (b) Gek di "Kampong Jawa" Barabai, Kalimantan Selatan Sumber: a)penulis; b)https://hdl.handle.net/20.500.11840/14825/

Gek adalah bangku sederhana yang terbuat dari bambu dan biasanya dibentuk dengan sandaran. Di masa lalu, penduduk setempat biasanya meletakkan kendi (teko dari tanah liat dan diisi dengan air minum) di Gek. Masyarakat meyakini hal itu sebagai Bukti ajaran dari Sunan Drajad, anggota Wali Songo yang hidup antara abad ke-15 hingga 16 sebagai salah satu penyebar Islam di Jawa Timur. Saat itu, Jawa sedang mengalami ketidakstabilan politik dan ekonomi. Kondisi tersebut membuat Sunan Drajad mendeklarasikan catur piwulang (empat saran) sebagai ajaran untuk merawat orang lain (Nashihin, 2012). Penempatan konstruksi Gek hampir mirip dengan Buk, khususnya di depan rumah. Perbedaannya adalah Buk biasanya terletak tegak lurus di depan rumah (Gbr. 1a), sedangkan Gek dibuat sejajar dengan arah rumah di belakangnya (Gbr. 1b). 
Konstruksi Buk telah diterapkan sejak pemerintah kolonial Belanda saat merancang infrastuktur kota di Indonesia pada masa penjajahan untuk mengatasi aliran air agar tidak menggenang di jalan saat hujan. Buk ini berfungsi agar manusia dan kendaraan bermotor tidak jatuh ke dalam got saat melintasi jembatan. Biasanya Buk memiliki ukuran tinggi 30-40 cm, dengan lebar 30-40 cm dan panjang 1-1,5 meter (lihat gambar 2 dan 3).

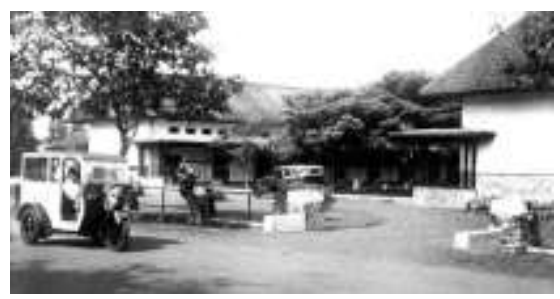

Gambar 2. Buk di depan sebuah sekolah di Kota Malang tahun 1943 Sumber: https://hdl.handle.net/20.500.11840/16894

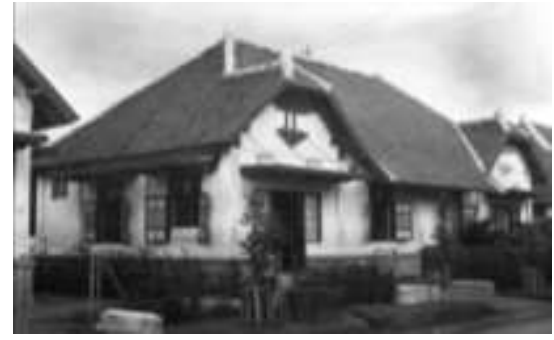

Gambar 3. Buk di depan sebuah rumah di Jalan Arjuna Kota Malang tahun 1929 Sumber: https://hdl.handle.net/20.500.11840/12322

\section{Buk di Dusun Malangsuko}

Seiring waktu, Buk ini diterapkan pula oleh masyarakat khususnya di perkampungan saat meningkatkan kualitas infrastruktur jalan lingkungannya. Menariknya, Buk yang awalnya digunakan untuk duduk-duduk, menjadi tempat berinteraksi, tempat bermain anak-anak, serta kegiatan sosial lainnya. Bahkan tempat yang tadinya dimiliki oleh pemilik rumah ini, menjadi ruang bersama dan akhirnya sering digunakan oleh masyarakat ketika proses sosial berlangsung.

Fenomena ini dapat dijumpai di Jalan Melati, Desa Malangsuko, Kabupaten Malang. Buk digunakan sangat intens oleh masyarakat di tempat ini. Masyarakat di Jalan Melati tidak melihat konstruksi sederhana ini hanya sekedar sebagai pengaman, namun memanfaatkannya sebagai tempat berinteraksi. Menurut mereka, Buk memiliki makna tertentu yang tidak dapat dipisahkan dari kehidupan sosial mereka, dan Buk ini biasanya digunakan untuk Jagongan (bahasa Jawa, terutama di daerah Malang, yang berarti mengobrol sambil duduk santai).

Dari pengamatan di lapangan, terdapat kecenderungan hubungan manusia atau pengguna dengan lingkungannya yang mengakibatkan penggunaan Buk dan jalan di tempat ini memiliki kontribusi yang signifikan terhadap terciptanya ruang sosial. Di lokasi ini, Buk tidak dilihat sebagai faktor penentu namun sebagai faktor pendukung. Adanya faktor lain seperti kondisi alam, pola permukiman, dan kondisi jalan merupakan satu kesatuan faktor yang memicu adanya ruang interaksi bagi masyarakatnya. Dalam penelitian ini, keberadaan Buk diidentifikasi sebagai salah satu elemen penting yang mendorong dan mendukung manusia di tempat ini beradaptasi dan menunjang kebutuhan dasar manusia dalam bersosialisasi. Hal inilah yang menjadikan fenomena ini sebagai representasi sebuah budaya yang masih dipelihara oleh masyarakat hingga sekarang dan menjadikannya sebuah fenomena ruang yang menarik untuk diteliti. 
Selain itu, Buk dapat dikatakan sebagai representasi dari sebuah fenomena spasialisasi. Dalam Bukunya, Places on the Margin, Shields (2013) mendefinisikan spatialisation (spasialisasi) sebagai bentuk spasial yang mengambil kegiatan sosial dan hal-hal yang berkaitan dengan material, fenomena atau proses dalam aspek geografi, sosiologi, perencanaan kota dan studi budaya. Secara umum istilah ini mengacu pada keseluruhan ruang sosial yang khas dari suatu waktu, tempat atau budaya. Dalam setiap ruang budaya, di dalamnya teridentifikasi memiliki nilai-nilai yang menjadi semangat (spirit) tempat tersebut sebagai bentuk kekhasan yang hanya terjadi di tempat itu, atau yang biasanya disebut sebagai Genius Loci.

Bila dikaitkan dengan arsitektur, spasialisasi merupakan sebuah bentuk tanggapan dalam terbentuknya arsitektur terhadap kekhasan suatu tempat atau ruang. Di satu sisi, spasialisasi tercapai secara hegemonik yang menempatkan dan melakukan aktivitas ruang di lokasi dan wilayah tertentu. Namun di sisi lain, spasialisasi terus berubah tergantung pada aktualisasi kinerja berkelanjutan orang-orang dari tatanan atau cara hidup dalam ruang tersebut. Biasanya ruang ini berubah menjadi diperebutkan (contested space) yang berfokus atas makna tempat, perilaku, atau reputasi lingkungan itu sendiri. Dapat dikatakan pula spasialisasi adalah cara untuk memperbaiki nilai-nilai budaya dan makna sosial yang penting, namun dapat pula berubah seiring waktu sesuai dengan semangat zaman.

Berdasarkan fenomena Buk di Jalan Melati dusun Malangsuko, penelitian ini bertujuan untuk mengidentifikasi lebih banyak tentang lokalitas yang mempengaruhi pembentukan Buk yang akhirnya membentuk ruang budaya. Selain itu, penelitian ini bertujuan untuk menggambarkan secara dialektis hubungan antara unsur-unsur hiasan dari lingkungan setempat dengan perilaku penduduknya. Melalui pendekatan spasialisasi, memungkinkan untuk mengekspresikan aspek intangible spasial pada objek studi secara logika dan mengelaborasikannya ke dalam bahasa dan tindakan yang lebih konkret, beserta konstruksi dan pengaturan kelembagaannya. Untuk itu, agar memudahkan dalam mengidentifikasi tingkat imajiner dari sebuah ruang, diperlukan elaborasi teori yang di dalamnya terdapat aspek yang dapat menjadi indikator dalam menarasikan aspek-aspek yang terjadi di ruang tersebut. Dalam penelitian ini, elemen Ekistics digunakan agar fenomena Buk di Jalan Melati Malangsuko dapat terjabarkan dengan baik agar pola pemanfaatan Buk dapat terdeskripsikan secara naratif.

\section{Ekistics}

Ekistics merupakan istilah Yunani yang digunakan untuk menjelaskan pengetahuan tentang permukiman. Permukiman diartikan sebagai tempat manusia untuk hidup dan berkehidupan di dalamnya (Rezende, 2016). Namun, secara etimologis, ekistics mempunyai arti lebih luas dari permukiman. Di dalamnya termasuk pengertian mengenai hubungan antara manusia, manusia dengan masyarakat dan dengan alamnya (hubungan dialektika).

Pemikiran awal ekistics telah dimulai sejak tahun 1940-an. Namun sebagai ilmu, ekistics baru ditulis secara sistematis oleh Constantinos A. Doxiadis pada tahun 1967. Teori Ekistics menyebutkan bahwa permukiman terdiri atas; the content (isi) yaitu manusia dan the container yaitu tempat fisik manusia tinggal yang meliputi elemen alam dan buatan. Lebih jauh lagi, isi dan tempat dapat dibagi lagi menjadi lima elemen utama yang disebut sebagai elemen ekistics, yaitu: Nature (Alam), Man (Manusia), Society (Masyarakat), Shells (Bangunan/Naungan), Network (Jaringan). 


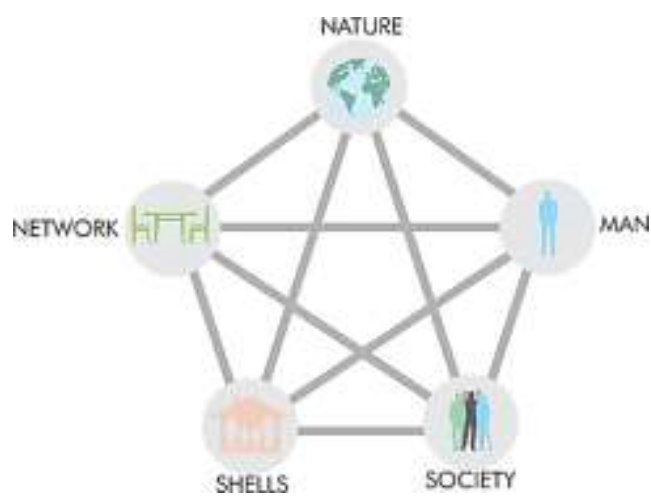

Gambar 4. Keterkaitan Lima Elemen Ekistics

Kelima elemen ini terelaborasi bersama dalam terbentuknya suatu permukiman. Alam (nature) merupakan wadah manusia ( $\mathrm{man}$ ) yang melakukan kegiatan sosial dengan sesamanya dan membentuk institusi bernama masyarakat (society). Kelompok sosial tersebut membutuhkan tempat untuk berlindung/bernaung dalam melakukan kegiatan, sehingga menciptakan rumah (shell). Rumah atau bangunan berkembang semakin kompleks sehingga membutuhkan jaringan penghubung (network) sebagai penunjang berfungsinya suatu lingkungan (Doxiadis, 1968). Dalam lima elemen ini terdapat juga ilmu ekonomi, teknik, sosial, politik dan kebudayaan. Ekistics membahas ilmu-ilmu tersebut, sehingga dapat dikatakan bahwa ekistics merupakan ilmu mengenai permukiman, Bukan hanya mengenai manusia, alam, jejaring, naungan maupun masyarakat semata (Rezende, 2016).

\section{METODE}

Secara umum, penelitian ini dilakukan dengan menggunakan mix-method approach secara eksploratif (Creswell, 2014). Penelitian ini diawali dengan mengkaji kondisi riil Buk di lokasi melalui observasi lapangan untuk mendapatkan gambaran Buk secara lengkap. Dalam observasi lapangan, in-depth random interview dilakukan terhadap masyarakat yang ditemui untuk menggali informasi bagaimana peran Buk dalam terciptanya ruang budaya di desa ini.

Melalui perspektif Ekistics, spasialisasi Buk di Jalan Melati Malangsuko dibaca dengan menggunakan parameter Nature, Man, Society, Shells dan Network (Doxiadis, 1968). Untuk memverifikasi narasi pembacaan fenomena Buk tersebut, dilakukan pula kuantifikasi hasil kajian kualitatif tersebut dengan menyebarkan kuesioner (terlampir) kepada 33 kepala keluarga yang merupakan penghuni tetap dari 35 rumah yang berada di sepanjang Jalan Melati Desa Malangsuko (warga RT 23 dan 24 RW 9 Desa Malangsuko). Isi kuesioner merupakan penerjemahan parameter ekistics ke dalam bentuk pertanyaan yang mudah dipahami oleh masyarakat setempat.

\section{HASIL DAN PEMBAHASAN}

\section{A. Kondisi Eksisting Jalan Melati}

Jalan Melati merupakan jalan desa yang menjadi jalan penghubung antar Permukiman di Dusun Malangsuko. Jalan Melati menghubungkan Jalan raya Malangsuko yang merupakan jalan utama menuju kawasan wisata Taman Nasional Bromo Tengger Semeru dari Kota Malang. Jalan ini merupakan bagian dari permukiman RT 23 dan 24, RW 9 Desa Malangsuko Kecamatan Tumpang Kabupaten Malang. Pada ujung barat jalan terdapat jalan dengan perkerasan berupa batu sebagai jalan menuju SMK Multimedia Tumpang sedangkan pada 
ujung Timur terdapat jalan Raya Malangsuko. Jalan ini membentang lurus sepanjang 161,3 meter dari Timur ke barat dengan kondisi jalan sudah teraspal selebar 2,7 meter.

Masyarakat yang tinggal di Jalan Melati merupakan warga yang terdaftar pada RW 9 dan terbagi ke dalam 2 RT yakni RT 23 dan 24. Jumlah warga yang tinggal di sepanjang Jalan Melati pada permukiman ini kurang lebih berjumlah 121 jiwa yang tinggal dalam 33 rumah dari 35 rumah, dengan rincian 33 rumah berpenghuni tetap sedangkan dua rumah lainnya merupakan rumah kontrakan yang sedang kosong saat penelitian ini dilakukan (lihat gambar 6). Dari data di lapangan menunjukkan bahwa setiap rumah rata-rata memiliki empat penghuni.
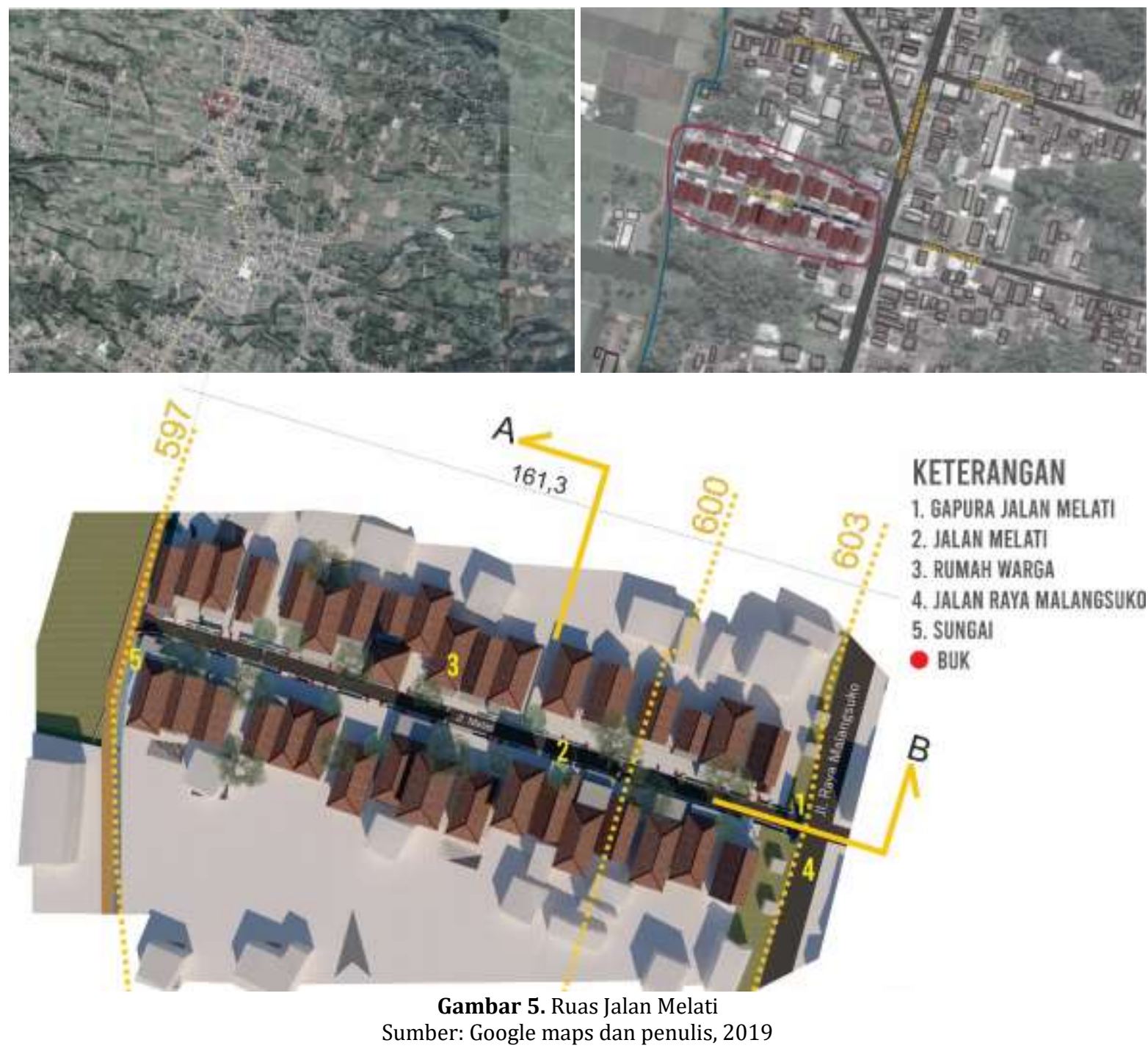

Pada sebelah kanan dan kiri Jalan Melati, terdapat drainase yang menghubungkan aliran air dari jalan raya Malangsuko di sebelah timur menuju sungai yang berada di sebelah barat. Drainase ini juga menyalurkan air limbah rumah tangga dari rumah-rumah warga menuju sungai. Adanya drainase di depan rumah menjadikan warga setempat membuat jembatan kecil penghubung antara jalan dengan rumah untuk memudahkan penghuninya melintas dan beraktivitas. Pada kanan dan kiri jembatan ini, dibangun sebuah struktur sederhana berbentuk balok yang berfungsi sebagai pengaman yang dinamakan warga sebagai Buk. 

Afidz Aditya Utama

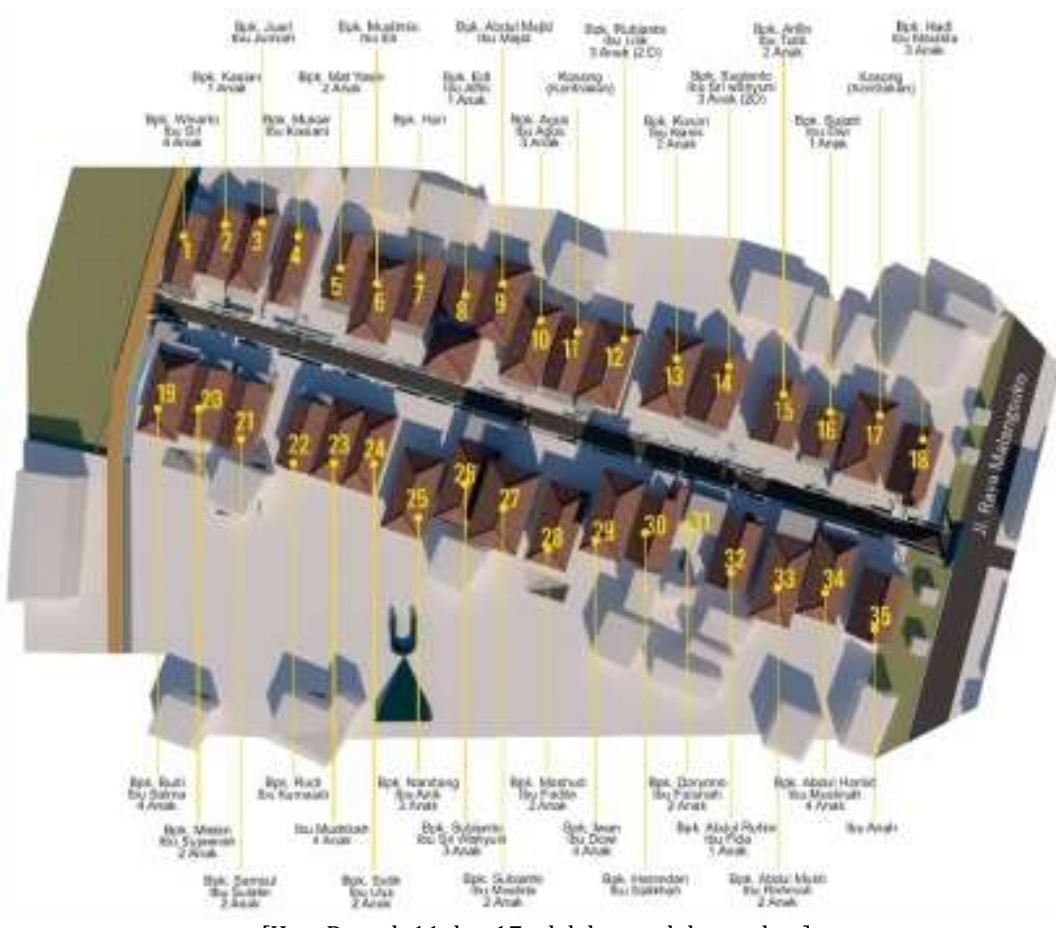

[Ket:: Rumah 11 dan 17 adalah rumah kontrakan]

Gambar 6. Status Rumah dan Pemiliknya

Pada Jalan Melati, Buk diidentifikasi berdasarkan dua kategori kepemilikan yakni Buk yang dimiliki oleh individu yaitu Buk yang merupakan bagian dari pemilik rumah serta Buk yang dimiliki oleh warga secara bersama. Buk yang dimiliki secara bersama berada pada ujung jalan Melati serta gang kecil yang menghubungkan jalan di barisan kedua Jalan Melati (lihat gambar 7). Berdasarkan wawancara dengan warga, Buk ini dibangun menggunakan dana desa yang dialokasikan untuk perbaikan sarana prasarana desa.

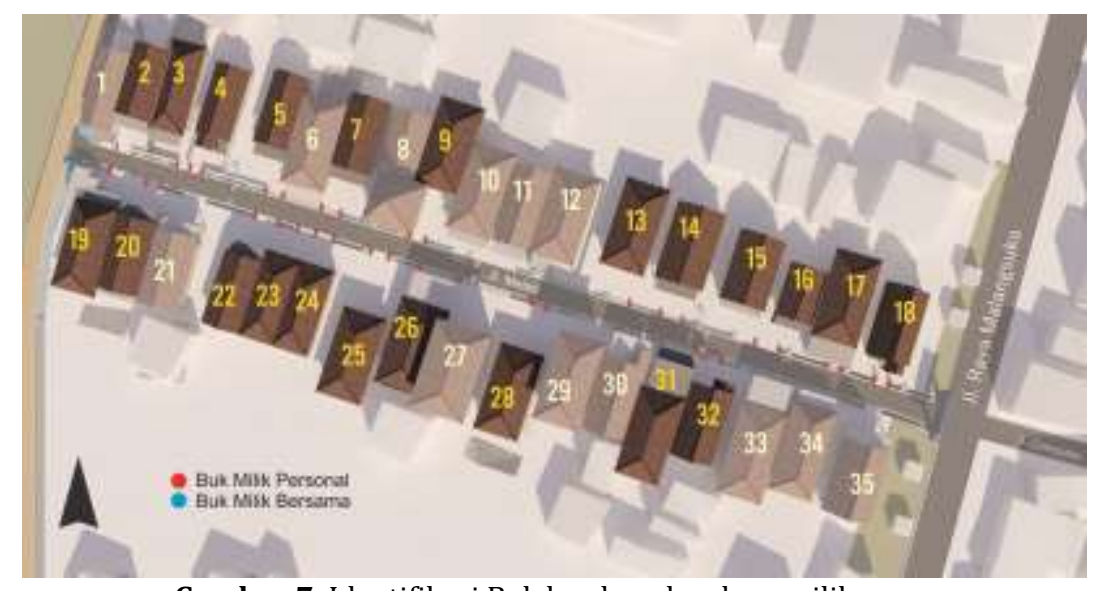

Gambar 7. Identifikasi Buk berdasarkan kepemilikannya

\section{B. Identifikasi Ekistics di Jalan Melati}

Menurut Doxiadis (1967) terdapat lima elemen dalam sebuah permukiman atau yang disebutnya sebagai Ekistics, yakni Nature (alam), Man (manusia), Society (masyarakat), Shells (naungan) serta Network (jaringan). Bila dikaitkan dengan kondisi di lapangan, kelima elemen ini dapat diidentifikasikan sebagai berikut:

1. Nature : Kondisi alam (iklim, suhu, topografi) di jalan Melati

2. Man : Kondisi manusia yang tinggal di jalan Melati secara individu 
3. Society : Keadaan sosial budaya masyarakat jalan Melati

4. Shells : Kondisi (bentuk, orientasi) rumah di sepanjang jalan Melati

5. Network: Kondisi jalan serta infrastruktur (drainase) pada jalan Melati

Kelima elemen ekistics ini saling berpengaruh satu dengan yang lainnya sehingga keterikatan ini memiliki pengaruh yang tidak dapat terlepaskan dalam pembentukan sebuah pola permukiman.

\section{Alam}

Alam merupakan elemen pertama dari urutan kombinasi elemen eksitics. Alam menjadi wadah manusia untuk hidup dan beraktivitas, sehingga kondisi alam sangat berpengaruh terhadap semua yang ada di dalamnya termasuk ke empat elemen eksitics yang lain.

Jalan Melati berada di titik koordinat $7^{\circ} 59^{\prime} 41.6^{\prime \prime S}$ dan $112^{\circ} 45^{\prime} 37.2^{\prime \prime} E$ dan berada di ketinggian $600 \mathrm{mdpl}$ menjadikan tempat ini berada di dataran tinggi yang memiliki suhu rata-rata $23,7^{\circ} \mathrm{C}$ (berdasarkan en.climate-data.org). Suhu yang terbilang cukup dingin karena area ini terletak $25 \mathrm{~km}$ dari Gunung Bromo dan Gunung Semeru. Selain udara, kondisi topografi yang berkontur menjadikan jalan serta rumah warga di Jalan Melati mengikuti kondisi setempat dengan kontur yang lebih tinggi pada sisi timur di sisi jalan raya Malangsuko.

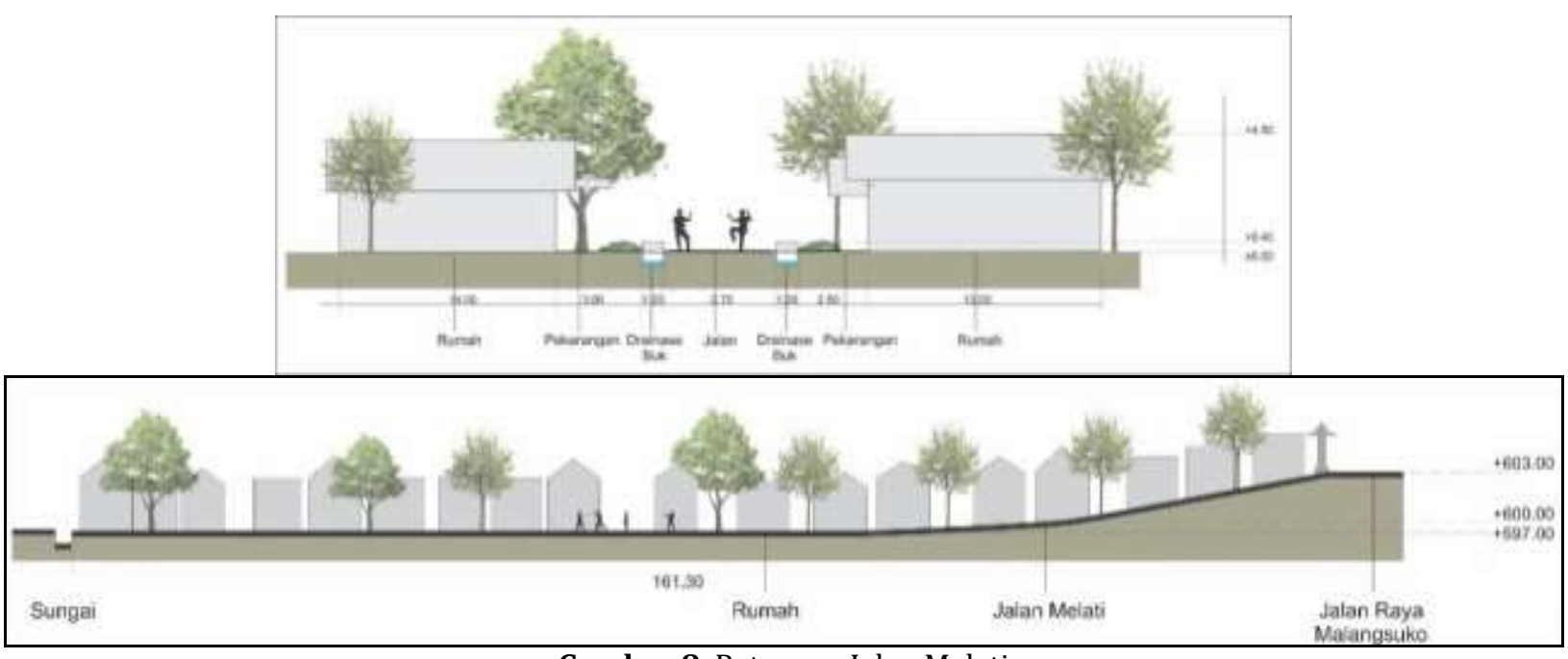

Gambar 8. Potongan Jalan Melati

Adanya perbedaan kontur ini menjadikan terdapat aliran drainase dari arah timur ke barat. Dari potongan melintang dapat dilihat bahwa di kanan dan kiri jalan Melati terdapat drainase yang berfungsi sebagai saluran air dari drainase Jalan Raya Malangsuko menuju sungai di sebelah barat permukiman. Akibat adanya saluran air, warga membangun jembatan kecil di atas aliran drainase untuk menghubungkan jalan dengan rumah agar dapat diakses dengan mudah. Untuk mengamankan aksesibilitas ini, dibangun pula Buk agar manusia ataupun kendaraan dapat aman saat melintas.

\section{Manusia}

Berdasarkan hasil pendataan, warga di Jalan Melati terdiri dari 90\% suku Jawa, 6\% suku Madura dan 4\% sisanya campuran (data RW 9). Dilihat dari jumlahnya, suku Jawa 
mendominasi permukiman ini, sehingga budaya yang berkembang pada permukiman ini merupakan hasil dari budaya Jawa yang berakulturasi dengan budaya lain termasuk budaya Madura yang merupakan minoritas dalam permukiman ini.

Keberadaan suku Jawa yang dominan dan asimilasi budaya Madura ini menjadikan cara berkehidupan di dusun ini guyub dan rukun. Budaya asal masing-masing suku teradopsi dan terwujudkan dalam cara manusianya bersosialisasi. Tidak mengherankan ruas jalan Melati akhirnya menjadi tempat warga mengekspresikan segala aktivitasnya. Seperti yang dikemukakan Pangarsa dan Prijotomo (2010), jalan inipun menjadi pelataran baik di waktu pagi, siang bahkan hingga malam hari. Akhirnya, beberapa elemen di 'pelataran' ini pun digunakan, seperti Buk yang akhirnya menjadi tempat untuk duduk warga.

Persepsi masyarakat di sini terhadap Buk dipengaruhi oleh faktor internal serta eksternal. Faktor internal ini dipengaruhi dari dalam diri manusia itu sendiri, sedangkan faktor eksternal dipengaruhi oleh pengalaman selama hidup sehingga mempengaruhi pola pikir dan kebiasaan. Dalam penggunaan Buk, faktor eksternal pada diri manusia di Jalan Melati terbentuk karena adanya aktivitas yang frekuentif terjadi pada Buk, misalnya saat orang dewasa menggunakan Buk sebagai tempat duduk, secara tidak sadar anak-anak akan mempraktekkan serta mengimplementasikan apa yang mereka lihat dalam aktivitas mereka bermain (lihat gambar 9).

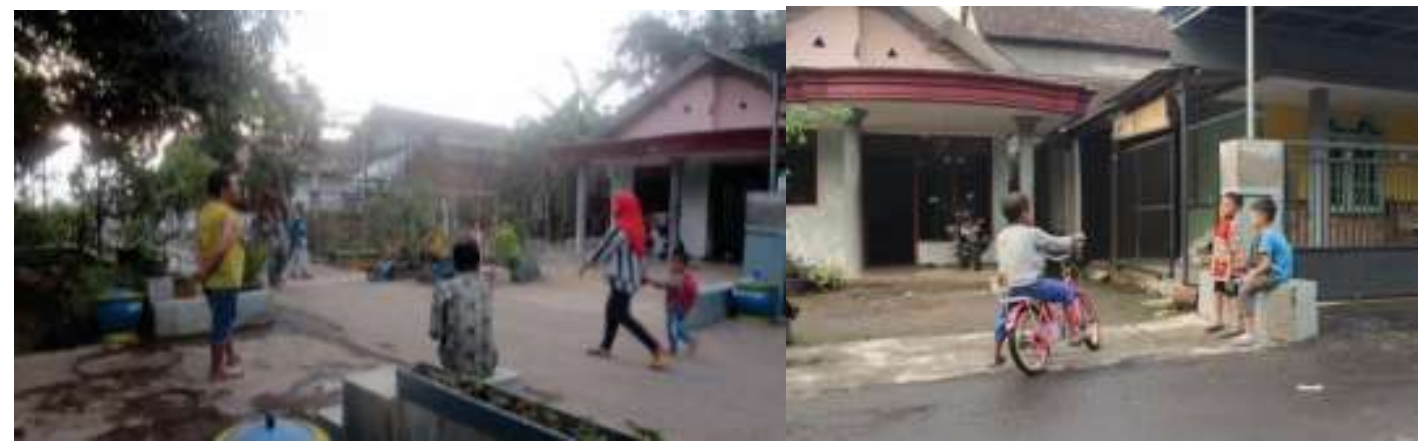

Gambar 9. Orang dewasa (ki) dan (hasil persepsi) anak-anak (ka) jagongan

Berbagai aktivitas yang terjadi di sekitar Buk yang dilakukan oleh masyarakat akan memberikan pengaruh vis a vis terhadap pola pikir manusia secara individu (internal). Oleh karena adanya kebiasaan ini, pengaruh internal manusia dalam memahami kejadian di sekitarnya menjadi stimulus yang kuat dalam membentuk cara pandang bahwa jalan dan Buk merupakan ruang bersama. Fenomena ini dianggap sebagai bagian dari kebiasaan yang membudaya. Akhirnya Buk menjadi tempat ekspresi segala macam aktivitas seperti tempat mengobrol santai (jagongan) dan tempat bermain bagi anak. Kegiatan ini secara langsung menstimulus anak menganggap bahwa lingkungan ini adalah bagian mereka tumbuh dan ketika dewasa mereka akan mengenal jalan dan Buk sebagai tempat untuk berinteraksi sebagaimana halnya orangtua mereka menggunakan ruang tersebut.

Selain dari hasil pengamatan, terdapat hasil wawancara terhadap anak-anak untuk menanyakan bagaimana menurut mereka makna dari Buk itu sendiri, mereka menganggap bahwa Buk itu sebagai tempat duduk atau tempat mereka bermain. Hal ini menunjukkan proses pertukaran informasi terjadi dengan sendirinya seiring berjalannya waktu (dapat dilihat pada Gambar 10). 


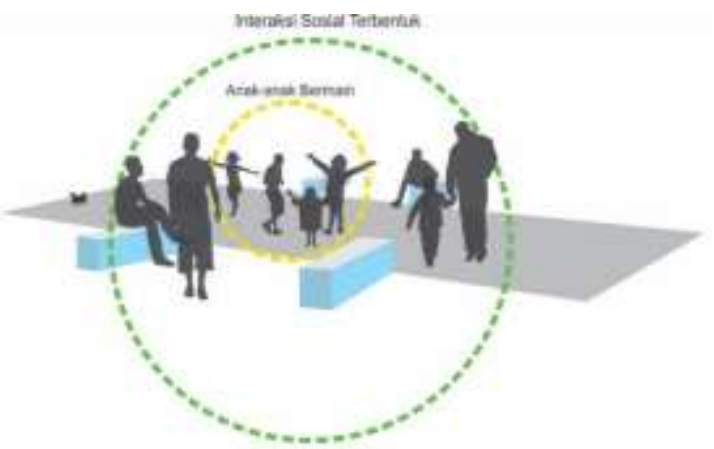

Gambar 10. Pembentukan persepsi anak-anak dalam menggunakan Buk

\section{Masyarakat}

Manusia membutuhkan sosialisasi dengan sesamanya sebagai wujud andil kehidupan bermasyarakat. Di Jalan Melati, terdapat beberapa kegiatan masyarakat seperti tahlilan yang digelar setiap hari rabu malam untuk wanita dan kamis malam untuk pria. Selain tahlilan, terdapat kegiatan rutin arisan kaum ibu setiap minggu sore dan kegiatan insidentil seperti kegiatan saat hari kemerdekaan. Kegiatan ini bertujuan untuk menambah tali persaudaraan antar warga di RT 23 dan 24. Kegiatan yang dilakukan oleh masyarakat secara rutin baik kegiatan rohani (tahlilan, pengajian) maupun kegiatan yang bersifat umum (arisan, perlombaan kemerdekaan) ini selalu menggunakan jalan, sehingga tidak jarang kegiatan ini menyebabkan ditutupnya ruas jalan Melati. Bagi sebagian besar masyarakat Nusantara, kegiatan warga yang mengakibatkan tutupnya jalan merupakan fenomena yang dapat diasosiasikan sebagai waktu berkumpul bersama seluruh anggota keluarga di tempat tersebut. Oleh karena itu, saat acara berlangsung, dusun atau kawasan ini menjadi 'rumah' bagi masyarakat dan jalan (seakan-akan) menjadi ruang keluarga. Tentu saja, interior di dalam ruang ini digunakan untuk bersantai, misalnya Buk yang seringkali digunakan sebagai tempat duduk bagi warga saat mempersiapkan acara maupun mengikuti acara.

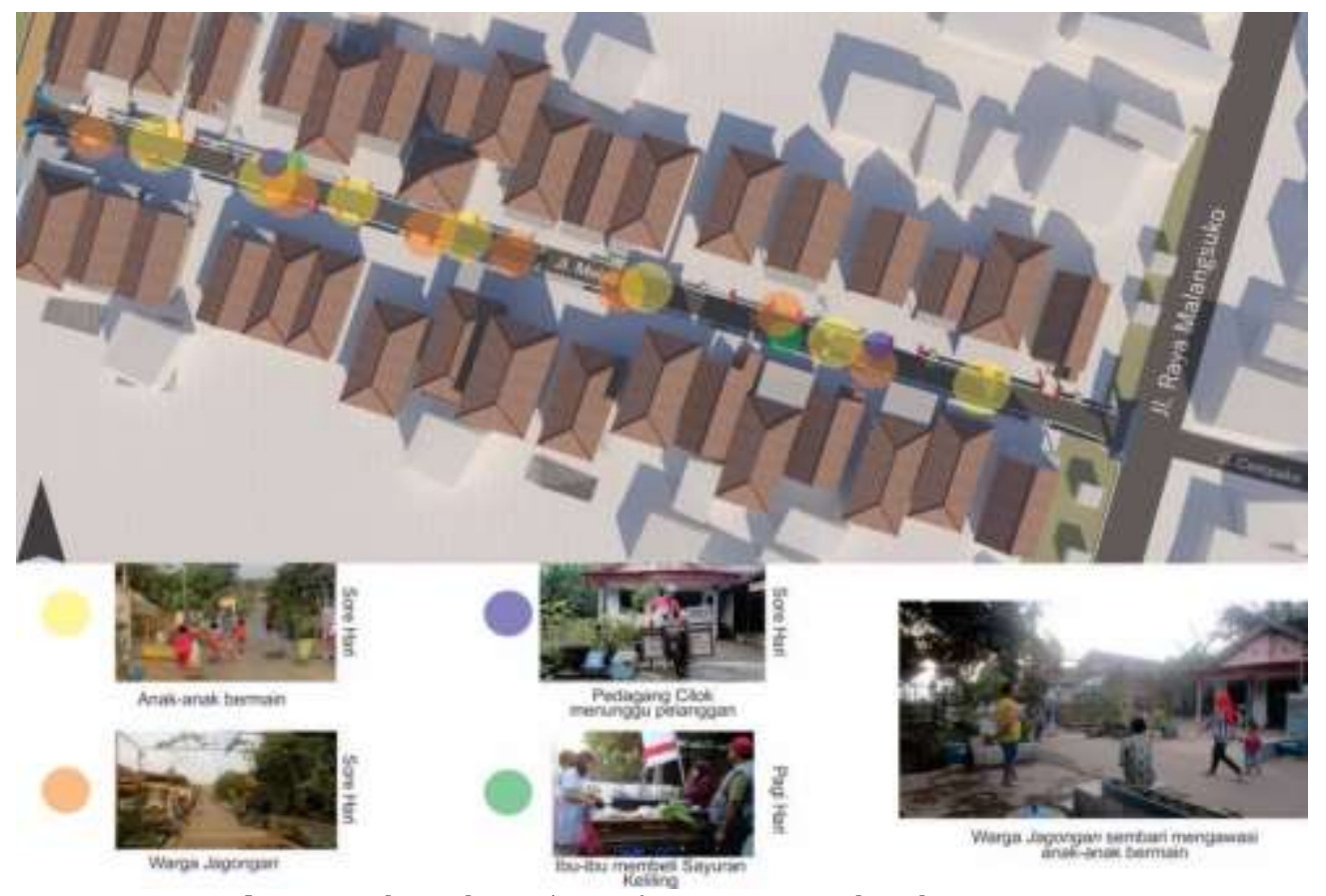

Gambar 11. Jalan sebagai 'ruang' tempat warga beraktivitas 
Selain itu, wujud sosialisasi masyarakat setempat tampak dari kegiatan duduk-duduk yang dilakukan oleh masyarakat untuk mengisi waktu luang sembari bertemu dan menyapa orang yang melintasi Jalan Melati. Adanya interaksi kecil ini membuat masyarakat hidup semakin mengenal satu sama lain sehingga tercipta suatu hubungan sosial yang erat antar warga. Contoh lain yaitu saat masyarakat menggunakan Buk sebagai tempat duduk dalam acara pemilihan kepala RW yang diselenggarakan di salah satu rumah warga (lihat gambar 12). Warga memanfaatkan jalan sebagai ruang dalam melaksanakan kegiatan pemilihan tersebut, dan Buk pun digunakan sebagai 'kursi'. Masyarakat menandai jalan ini dengan memasang karpet di jalanan untuk menyatakan 'okupansi' terhadap ruang tersebut. Ruang yang sebelumnya dapat dilewati dengan bebas oleh publik seketika menjadi ruang 'privat' bagi warga dengan adanya fenomena ini.
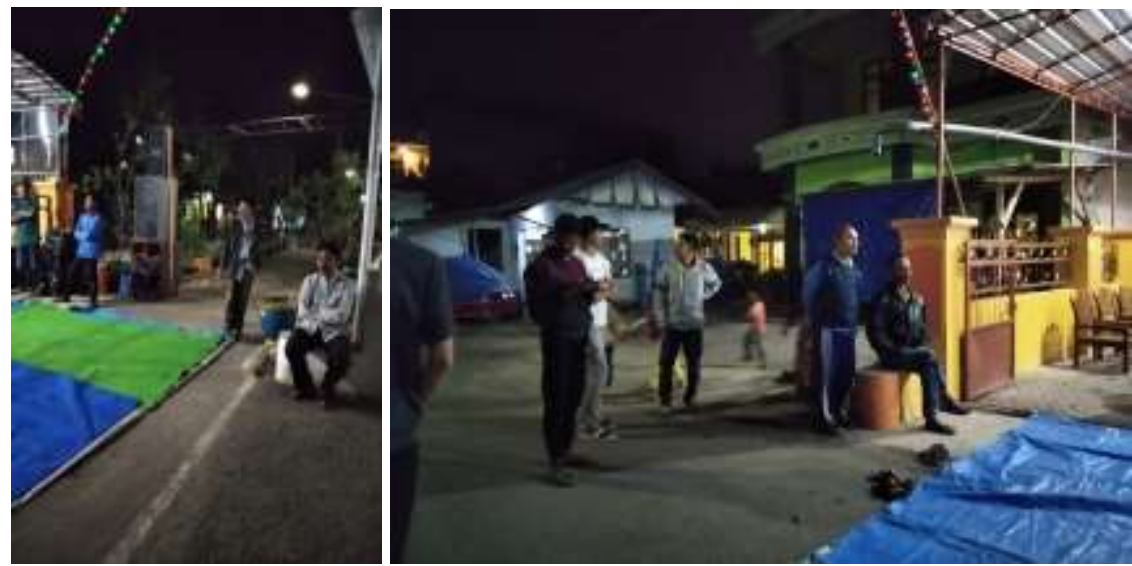

Gambar 12. Masyarakat menggunakan Buk sebagai tempat duduk pada acara pemilihan RW

\section{Naungan}

Naungan atau rumah yang dibentuk oleh manusia merupakan kebutuhan dasar yang berupa rasa aman dan perlindungan dari alam. Naungan pada Jalan Melati berupa rumahrumah warga yang terpola linear mengikuti jalan yang ada pada permukiman ini. Terdapat 35 rumah yang berada di sepanjang Jalan Melati dengan 18 rumah yang terletak di sebelah utara jalan dan 17 rumah di sebelah selatan ruas jalan Melati. Semua rumah memiliki orientasi hadap ke arah jalan Melati (Gambar 13). Oleh karena adanya saluran drainase di pinggir jalan, maka diperlukan jembatan (dan Buk sebagai pengamannya) untuk menunjang aksesibilitas penghuninya.

Dalam penggunaan Buk, orientasi rumah ini memiliki pengaruh terhadap aktivitas masyarakat yang dilakukan di sekitarnya. Seperti apa yang dikemukakan oleh Jacobs (1993) bahwa jalan yang baik merupakan jalan yang memiliki eyes atau mata yang mengawasi jalan. Pada Jalan Melati, rumah menjadi mata bagi aktivitas yang terjadi di Jalan Melati.

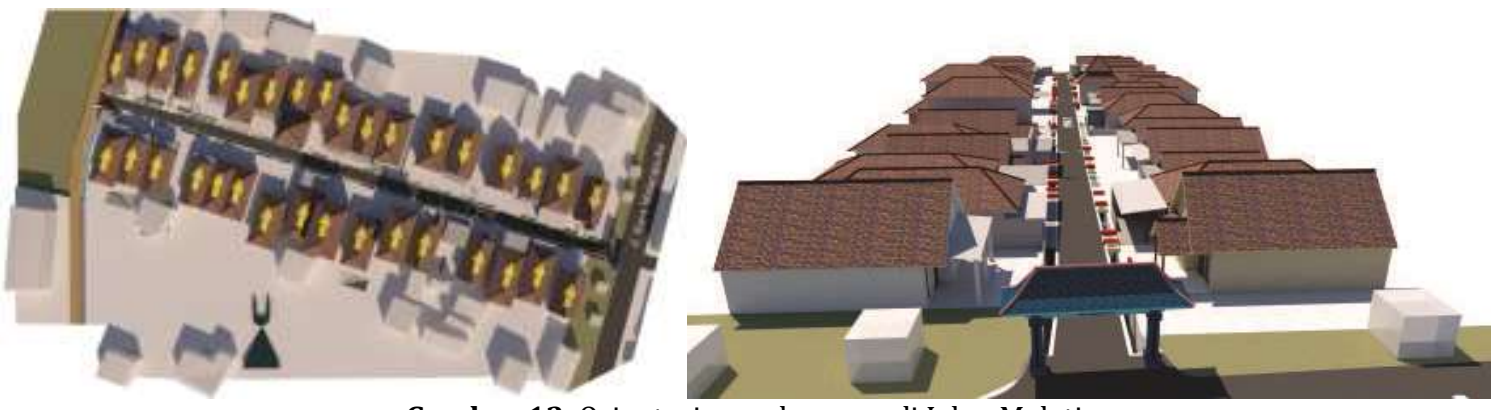

Gambar 13. Orientasi rumah warga di Jalan Melati 
Menurut masyarakat, mereka merasa aman saat berkegiatan di jalan dan sekitar Buk karena orientasi rumah yang menghadap ke jalan. Orientasi rumah sekaligus memberikan akses pengawasan terhadap berbagai macam aktivitas, terutama saat anak-anak bermain di depan rumah. Hal ini diperkuat dengan selalu terBukanya pintu rumah jika ada penghuni di dalamnya. Sebagai tanggapan terhadap segala aktivitas yang terjadi di luar (jalan), akan dapat dengan mudah terpantau dan segera dapat terakses secara aman dengan adanya jembatan ber-Buk di depan rumah.

\section{Jaringan}

Jalan sebagai jaringan utama penghubung memiliki peran penting bagi keberlangsungan suatu permukiman, terlebih lagi di Nusantara. Seperti terlihat di Jalan Melati yang memperlihatkan jalan dalam menunjang masyarakat untuk bersosialisasi. Di sini, jalan tidak hanya sekedar jalan untuk akses kendaraan, melainkan menjadi identitas ruang bersama yang dapat digunakan sebagai tempat bermain, bersosialisasi serta aktivitas sehari-hari lainnya (Pangarsa dan Prijotomo, 2010). Ditambah dengan adanya Buk, masyarakat merasa terfasilitasi untuk melakukan lebih banyak kegiatan di jalan. Buk yang digunakan masyarakat untuk duduk menjadi salah satu faktor pendukung aktivitas di jalan ini semakin intens.

Walaupun awalnya Buk merupakan bagian dari rumah perorangan/individu, namun seiring berjalannya waktu serta semakin intensnya aktivitas membuat Buk ini seolah-olah menjadi milik bersama karena aksesnya yang terbuka. Nilai kebersamaan yang kental menjadikan tidak adanya larangan dari pemilik Buk dan akhirnya Buk ini menjadi milik bersama dan digunakan bagi siapapun yang tinggal di sepanjang jalan ini. Penggunaan jalan serta fasilitasnya ini hampir setiap hari dilakukan oleh masyarakat, dari anak-anak hingga dewasa memanfaatkan ruang ini. Interaksi sosial antar sesama terbangun dari kecil hingga diturunkan dari generasi ke generasi.

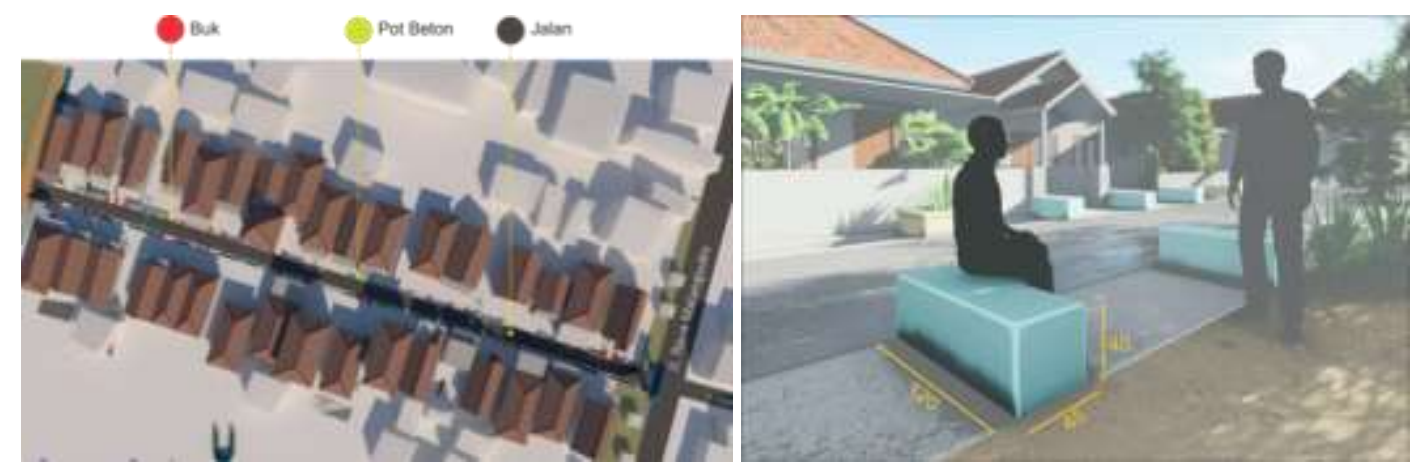

Gambar 14. Jaringan jalan Melati dan detail Buk

\section{Identifikasi Kuantitatif}

Dari hasil analisis kualitatif yang dijabarkan sebelumnya, diperlukan adanya data kuantitatif untuk mendukung hasil analisis kualitatif yang sebelumnya telah dipaparkan. Data kualitatif tersebut diolah menjadi sebuah pernyataan dalam bentuk kuesioner (lihat lampiran) yang kemudian diisi oleh 33 kepala keluarga yang menjadi warga tetap penghuni rumah di sepanjang jalan Melati. Hasil kuesioner kemudian dirangkum hingga mendapatkan mean atau rata-rata dari jawaban masyarakat (lihat tabel 1). Rata-rata masyarakat menjawab netral hingga sangat setuju karena mereka merasa sependapat dengan pernyataan tersebut. 
Tabel 1. Hasil Kuesioner

\begin{tabular}{|c|c|c|c|}
\hline No. & Pernyataan & Capaian & Mean \\
\hline 1 & $\begin{array}{l}\text { Adanya aliran air, perlu dibangun drainase untuk memperlancar } \\
\text { aliran air }\end{array}$ & \multirow{3}{*}{$\begin{array}{l}\text { Terbentuknya } \\
\text { Buk }\end{array}$} & 4.12 \\
\hline 2 & $\begin{array}{l}\text { Untuk menghubungkan rumah dan jalan yang dipisahkan } \\
\text { drainase diperlukan jembatan untuk akses }\end{array}$ & & 4.21 \\
\hline 3 & Jembatan perlu dibangun pengaman (Buk) di kanan dan kirinya & & 3.52 \\
\hline 4 & $\begin{array}{l}\text { Selain sebagai pengaman jembatan, saya menganggap Buk } \\
\text { sebagai tempat duduk dan tempat berinteraksi sosial }\end{array}$ & Man & 4.06 \\
\hline 5 & $\begin{array}{l}\text { Masyarakat menggunakan fasilitas berupa Buk untuk } \\
\text { berinteraksi dan melakukan kegiatan sosial. }\end{array}$ & Society & 4.12 \\
\hline 6 & $\begin{array}{l}\text { Rumah berperan untuk "mengawasi" aktivitas yang terjadi di Buk } \\
\text { dan jalanan sehingga lebih merasa aman. }\end{array}$ & Shells & 4.33 \\
\hline 7 & Aktivitas di sekitar Buk sering terjadi di Pagi dan Sore hari. & Nature & 4.39 \\
\hline 8 & $\begin{array}{l}\text { Dengan adanya Buk, menjadikan Jalan sebagai ruang bersama } \\
\text { karena sering terjadi interaksi sosial. }\end{array}$ & Network & 4.27 \\
\hline 9 & $\begin{array}{l}\text { Buk memberikan dorongan terjadinya interaksi sehingga } \\
\text { memberikan dampak positif bagi keberlangsungan kehidupan } \\
\text { bermasyarakat }\end{array}$ & $\begin{array}{l}\text { Ruang } \\
\text { Budaya }\end{array}$ & 4.58 \\
\hline
\end{tabular}

Berikut adalah hasil yang ditampilkan dalam diagram pie dari sembilan pertanyaan yang diajukan:

1. Adanya aliran air, perlu dibangun drainase untuk memperlancar aliran air.

Dari total 33 jawaban, sebanyak 64\% menjawab setuju dengan pernyataan ini bahwa adanya aliran air akibat dari kondisi topografi di Jalan Melati perlu dibangun drainase untuk memperlancar aliran air tersebut. Tidak ada responden yang menjawab tidak setuju hingga sangat tidak setuju.

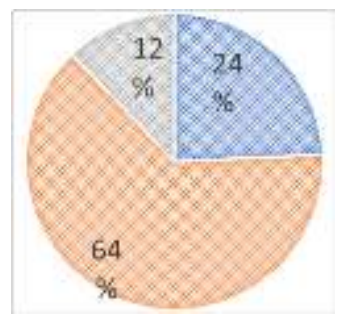
- Sangat Setuju
- Setuju
- Netral
- Tidak Setuju
- Sangat Tidak Setuju

2. Untuk menghubungkan rumah dan jalan yang dipisahkan drainase diperlukan jembatan untuk akses.

Dari total 33 jawaban, sebanyak 49\% menjawab setuju, 36\% menjawab sangat setuju, sedangkan sisanya menjawab netral. Hal ini menunjukan bahwa jembatan yang menghubungkan rumah dan jalan memerlukan jembatan sebagai akses untuk menunjang aktivitas penghuni rumah.

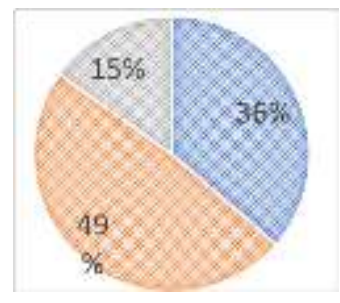

- Sangat Setuju

- Setuju

- Netral

- Tidak Setuju

- Sangat Tidak Setuju 
3. Jembatan perlu dibangun pengaman (Buk) di kanan dan kirinya.

Sebanyak 58\% jawaban menjawab netral terhadap diperlukannya Buk. Menurut mereka Buk diperlukan, namun seiring berjalannya waktu serta kebutuhan akan ruang untuk kendaraan roda empat perlu adanya pelebaran jalan yang mengakibatkan warga masih ragu dengan jawaban mereka.

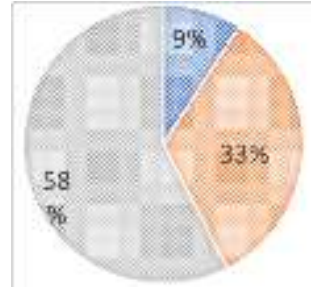
- Sangat Setuju
- Setuju
- Netral
- Tidak Setuju
- Sangat Tidak Setuju

4. Selain sebagai pengaman jembatan, saya menganggap Buk sebagai tempat duduk dan tempat berinteraksi sosial.

Sebanyak 52\% warga Jalan Melati menjawab setuju dengan pernyataan tersebut, membuktikan bahwa selain sebagai pengaman jembatan, Buk memiliki fungsi sebagai tempat duduk serta sebagai tempat berinteraksi.

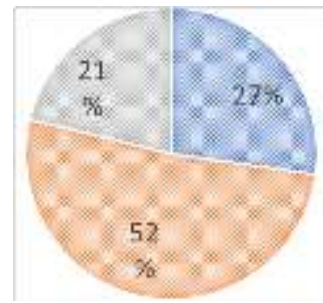
- Sangat Setuju
- Setuju
- Netral
- Tidak Setuju
- Sangat Tidak Setuju

5. Masyarakat menggunakan fasilitas berupa Buk untuk berinteraksi dan melakukan kegiatan sosial.

Dari total 33 jawaban, sebanyak 52\% setuju dengan pernyataan di atas dan 30\% sangat setuju menggunakan fasilitas Buk sebagai penunjang dalam kegiatan sosial.

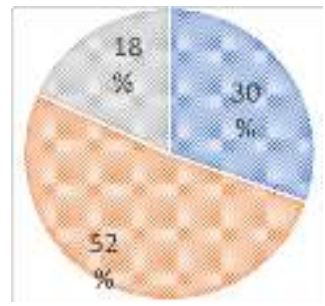
Sangat Setuju
- Setuju
Netral
- Tidak Setuju
- Sangat Tidak Setuju

6. Rumah berperan untuk 'mengawasi' aktivitas yang terjadi di Buk dan jalanan sehingga lebih merasa aman.

Naungan memiliki peran dalam penggunaan Buk, masyarakat merasa terawasi dengan keberadaan rumah yang berorientasi ke arah jalan. Dari total 33 jawaban, 52\% sangat setuju dan $30 \%$ setuju.

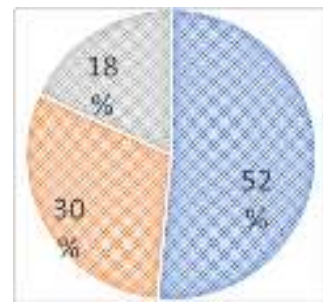

\author{
Sangat Setuju \\ Setuju \\ Netral \\ - Tidak Setuju \\ - Sangat Tidak Setuju
}


7. Aktivitas di sekitar Buk sering terjadi di Pagi dan Sore hari.

Sebagai variabel yang mempengaruhi aktivitas yang terjadi pada penggunaan Buk, faktor alam mempengaruhi pula pola aktivitas masyarakat. Masyarakat lebih memilih untuk melakukan aktivitas di waktu pagi dan sore hari.

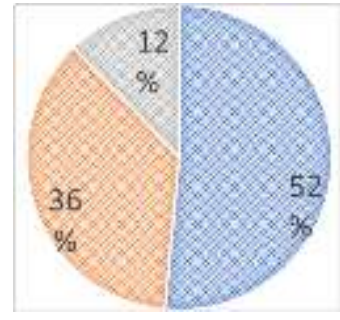

Sangat Setuju

- Setuju

Netral

- Tidak Setuju

- Sangat Tidak Setuju

8. Dengan adanya Buk, menjadikan jalan sebagai ruang bersama karena seringnya terjadi interaksi sosial.

Jaringan jalan mempengaruhi pula pola masyarakat dalam menggunakan Buk, salah satunya dengan adanya jalanan yang dilengkapi dengan Buk, warga memanfaatkannya sebagai tempat duduk di sela-sela aktivitas mereka di pinggir jalan.

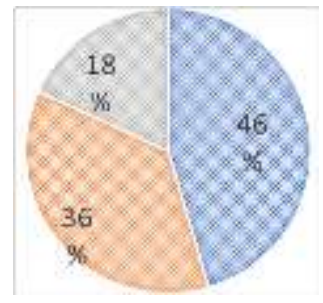

- Sangat Setuju

- Setuju

Netral

- Tidak Setuju

- Sangat Tidak Setuju

9. Buk memberikan dorongan terjadinya interaksi sehingga memberikan dampak positif bagi keberlangsungan kehidupan bermasyarakat.

Sebanyak 61\% responden menjawab sangat setuju dengan pernyataan bahwa Buk memberikan dorongan masyarakat untuk berinteraksi sehingga menimbulkan dampak positif bagi kerukunan dalam kehidupan bermasyarakat.

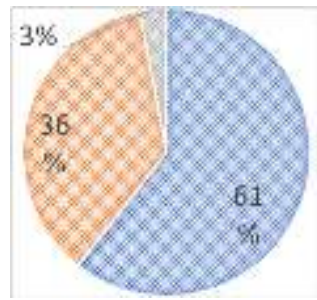

\author{
- Sangat Setuju \\ Setuju \\ Netral \\ - Tidak Setuju \\ - Sangat Tidak Setuju
}

Dari hasil jawaban masyarakat tersebut, dapat disimpulkan bahwa Buk merupakan hasil dari adaptasi penghuni permukiman terhadap kondisi alam serta kebutuhan untuk menunjang aktivitasnya. Adapun pertanyaan nomor tiga terkait dengan dibangunnya Buk sebagai pengaman jembatan, jawaban warga mendekati netral dengan nilai rata-rata 3.52 dengan berbagai alasan. Dari hasil wawancara, beberapa warga menjawab antara diperlukan dan tidak diperlukan. Alasan mengapa Buk tidak terlalu diperlukan karena adanya kebutuhan perlunya pelebaran jalan untuk kemudahan akses kendaraan roda empat. Hal ini bisa jadi mengakibatkan perlu merobohkan Buk dan menutup bagian atas drainase sepenuhnya. Tetapi, warga juga sadar bahwa mereka juga memerlukan Buk sebagai salah satu elemen penting dalam 'ruang' mereka tersebut, sehingga ratarata warga memilih menjawab netral untuk poin ini. 
Kelima elemen ekistics ini juga memiliki kaitan dengan keberadaan Buk di Jalan Melati. Dari hasil kuesioner didapat rentang nilai dari setuju hingga sangat setuju membuktikan bahwa hasil analisis kualitiatif yang dilakukan sebelumnya sesuai dengan apa yang dialami oleh warga Jalan Melati yang menunjukkan bahwa elemen ekistics memiliki pengaruh terhadap terbentuknya Buk di sini. Di samping itu, penggunaannya mendorong terciptanya spasialisasi yang khas di Jalan Melati dan akhirnya membentuk sebuah ruang budaya yang diteruskan dari generasi ke generasi. Hal ini dibuktikan dengan tanggapan pernyataan terakhir kuesioner bernilai 4.58 yang menandakan warga sependapat dengan pernyataan tersebut.

\section{Hubungan Elemen Ekistics dengan Ruang yang Terbentuk}

Melalui pemaparan elemen ekistics yang terjadi pada Jalan Melati, terdapat fenomena spasialisasi yang khas terbentuk dalam permukiman ini. Senada dengan konsep penghadiran ruang oleh Pangarsa dan Prijotomo (2010) bahwa ruang merupakan suatu penghadiran, bukan sesuatu yang sudah ada. Ruang tercipta jika terdapat aktivitas di dalamnya. Ruang-ruang yang terbentuk merupakan ruang yang intangible. Keberadaan ruang tersebut terbentuk karena adanya suatu aktivitas hasil interaksi sosial. Luas dari ruang tersebut bergantung pada seberapa intens manusia berinteraksi di dalamnya.

Fenomena ini tergambar jelas di Jalan Melati. Jalan menjadi ruang masyarakatnya berinteraksi. Intensitasnya dipengaruhi pula oleh alam. Tidak mengherankan bila interaksi masyarakat di Jalan Melati sering terjadi di saat pagi, sore dan malam yang cerah. Tidak di siang hari atau kala hujan turun karena faktor alam yang memaksa manusianya untuk bernaung.

Dalam berinteraksi di ruang jalan ini, masyarakat memanfaatkan Buk sebagai hasil adaptasi mereka dalam mengamankan aksesibilitas dari jalan ke area rumah. Buk digunakan untuk jagongan, mengawasi anak bermain, pemilihan perangkat RT/RW, lomba balap karung, dan segala macam aktivitas 'kebersamaan' lainnya. Perilaku ini membentuk pola pikir bagi masyarakat utamanya generasi muda mereka dalam memaknai ruang di jalan ini. Jalan inipun menjadi pelataran layaknya halaman rumah. Tidak mengherankan bila fenomena ini banyak terjadi di Nusantara, utamanya di Pulau Jawa. Jalan seringkali ditutup oleh karena okupansi masyarakatnya untuk beraktivitas layaknya di halaman sendiri, semisal pernikahan, kenduri dan lain-lain.

Pangarsa (2006) memandang bahwa dengan memelihara ruang tersebut, maka terbukalah kesempatan untuk berkehidupan bersama dengan keadilan, keseimbangan, kedamaian, keselarasan serta ketentraman. Hal ini merupakan semangat yang paling mendasar penghadiran ruang di Nusantara. Penggunaan Buk ini mendorong terciptanya pola spasialisasi yang khas pada masyarakat di Jalan Melati dalam bermukim. Energi di dalamnya sangat mempengaruhi aspek sosial budaya di tempat ini. Banyaknya kegiatan rutin yang dilakukan oleh masyarakat di koridor jalan semakin meningkatkan rasa sosial antar sesama penghuni dan menjadikan kerukunan antar warganya tetap terjaga dan semakin kuat.

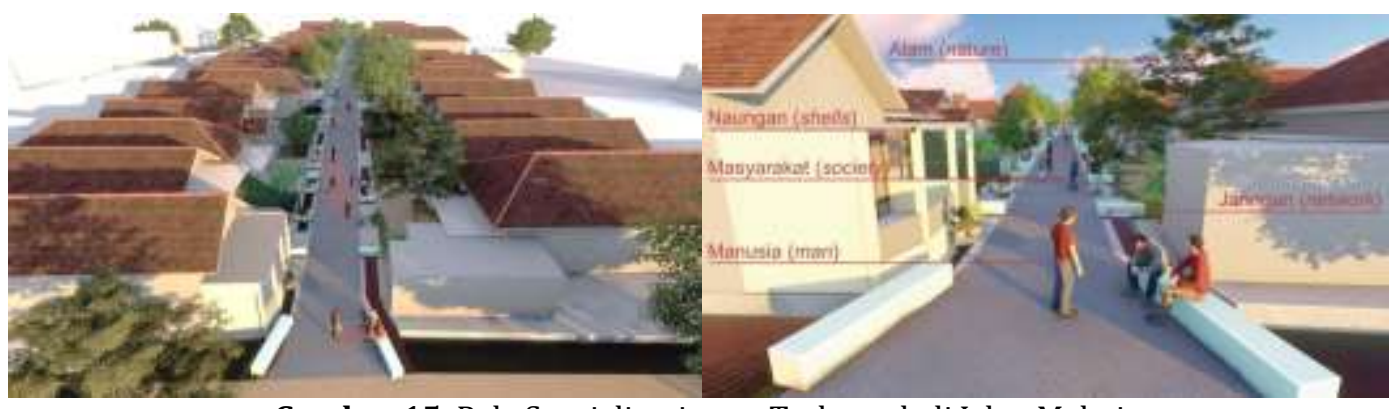

Gambar 15. Pola Spasialisasi yang Terbentuk di Jalan Melati 


\section{KESIMPULAN}

Berdasarkan hasil analisis terkait dengan fenomena penggunaan Buk dari perspektif ekistics didapat bahwa Buk memiliki keterikatan dengan lima elemen ekistics. Di Jalan Melati, Buk hadir sebagai hasil adaptasi manusia terhadap lingkungan alam (nature) yang kemudian dimanfaatkan oleh manusia ( $\mathrm{man}$ ) dan masyarakat (society) sebagai penunjang dalam berinteraksi di jalan (network). Adapun rumah (shells) menjadi 'kamar-kamar' bagi manusianya untuk bernaung sekaligus melihat/mengawasi segala macam interaksi mereka di [pelataran] jalan.

Dengan adanya aktivitas yang memanfaatkan Buk sebagai fasilitas pendukung, secara langsung mempengaruhi dan meningkatkan persepsi masyarakat Jalan Melati dalam merasakan spasialisasi yang tercipta. Persepsi ini semakin diperkuat dengan preseden dalam memandang penggunaan Buk sebagai tempat bermain bersama sejak kecil. Seiring waktu, Buk yang awalnya diciptakan fungsional menjadi memiliki makna tersendiri sebagai bagian dari ruang bersama pada permukiman di sepanjang Jalan Melati Malangsuko ini. Dari analisis eksploratori (kualitatifkuantitatif) yang dipaparkan sebelumnya membuktikan bahwa elemen ekistics terkait erat dalam penghadiran Buk dan kemudian kehadirannya mempengaruhi cara manusia di dalamnya berinteraksi.

Hasil adaptasi manusia terhadap elemen ekistics menghasilkan sebuah setting yang di dalamnya juga secara tidak sengaja melahirkan fenomena Buk. Dari cara hidup masyaraktnya, Buk kemudian muncul sebagai sebuah cara memandang dan memaknai wujud spasialisasi. Sebuah ruang budaya yang me-Nusantara. Fenomena spasial ini menjadi sebuah ruang yang memiliki energi dalam meningkatkan rasa sosial atau keakraban sesama penghuni. Ruang ini pula dapat menciptakan budaya kerukunan antar masyarakat yang hidup di sepanjang Jalan Melati semakin kuat dan mendorong terciptanya keadilan, keseimbangan, kedamaian, keselarasan serta ketentraman dalam kehidupan bermasyarakat. Selain itu, penelitian ini menunjukkan bahwa Nusantara memiliki segudang kekayaan fenomena bentuk kesederhanaan dalam adaptasi berarsitektur yang dapat membuktikan bahwa masyarakat Nusantara merupakan manusia yang menunjung tinggi nilai sosial dalam cara mereka bernaung.

\section{DAFTAR REFERENSI}

Creswell, J.W., (2014). Research Design: Qualitative, Quantitative and Mixed Methods Approaches: Fourth edition. Sage publications, Inc.

Darmiwati, R. (2000). Studi Ruang Bersama Dalam Rumah Susun Bagi Penghuni Berpenghasilan Rendah. DIMENSI (Jurnal Teknik Arsitektur), 28(2), 114-122.

Doxiadis, C.A. (1968). EKISTICS: An Introduction to the Science of Human Settlements. London: Hutchinson of London.

Doxiadis, C.A. (1970). Ekistics, the Science of Human Settlements. Science, v.170, no.3956, October 1970, p. 393 404

Indeswari, A., et al. (2013). Pola Ruang Bersama pada Permukiman Madura Medalungan di Dusun Baran Randugading (Common Space Pattern in Medalungan Madura Settlement in Baran Randugading Hamlet). Review of Urbanism and Architectural Studies, 11(1). https://doi.org/10.21776/ub.ruas.2013.011.01.4

Jacobs, J. (1993). The Death and Life of Great American Cities. New York, The Moder Library.

Nashihin. (2012). Teaching Humanism Sunan degrees. Journal of Humanities Vol.11 No. 1 January-June 2012: 67: Airlangga University Surabaya, Indonesia

Pangarsa, G.W. (2006). Merah Putih Arsitektur Nusantara. Yogyakarta, Andi Offset.

Pangarsa, G. W. dan J. Prijotomo. (2010). Rong: Wacana Ruang Arsitektur Jawa. Diakses melalui https://issuu.com/galihwpangarsa/docs/rong__wacana_ruang_arsitektur_jawa pada 2 Maret 2019.

Rezende, V. (2016). Urban planning in Guanabara State, Brazil: Doxiadis, from Ekistics to the Delos Meetings. Urban Planning in Guanabara State, Brazil: Doxiadis, from Ekistics to the Delos Meetings. https://doi.org/10.7480/iphs.2016.6.1332

Shields, R. (2013). Places on the margin: Alternative geographies of modernity. In Places on the Margin: Alternative 
Geographies of Modernity. https://doi.org/10.4324/9781315003269. Routledge.

Sholikhin, M. (2010). Ritual dan Tradisi Islam Jawa. Jakarta: PT Suka Buku.

Trancik, R. (1986). Finding Lost Space, Theories of Urban Design. Van Nostrand Reinhold, New York.

Tuan, Yi-Fu. (2001). Space and Place: The Perspective of Experience. Minneapolis: Minesotta Press. 